\title{
England and Sweden in the Time of William III and Anne
}

THE present article is intended to be introductory to others 1 treating in detail of the relations of George I of England with Charles XII of Sweden. Their hostility was the result of events which occurred in the years when George was only, to use the common term, elector of Hanover. These led him to exchange alliance with Sweden for confederation with her assailants, and he naturally sought to further his Hanoverian interests by the power of his new kingdom. But the necessities of commerce required that Great Britain and Sweden should remain, if possible, on friendly terms. They did so until in $\mathbf{1 7 1 0}$ on the one hand Queen Anne failed to comply with the impossible demand of Charles for the literal fulfilment of her guarantees of the treaties of Travendal and Alt-Ranstädt, and he on the other imposed restrictions on Baltic trade which could not be allowed. The queen's last ministry, pacific as its aims were, found itself obliged to equip a squadron for the protection of the northern traders. The same causes that compelled it to this action gave to George year after year British fleets for service in the Baltic. I propose now to present first some notes upon the Baltic trade, secondly a short survey of English relations with Sweden in the years 1688 to 1709 , and thirdly a more particular examination of the northern policy of the Oxford ministry.

In the first place we must remark that at the beginning of the eighteenth century the Baltic was practically a Swedish lake. The fleets of Denmark, the other naval power there, could not meet those of Sweden in the open. Charles XII inherited the whole coast round from the Sound to the frontier of Prussia, and on the southern shore Pomerania from the Oder to the Recknitz, and Wismar and its dependencies in Mecklenburg. Three-fourths of the coast were his. Russia had no outlet of her. own to the Baltic till Peter the Great early in the century built St. Petersburg and took Narva.

For commercial purposes five divisions of the north of Europe 
were recognised in England. Sweden and Finland were one; Denmark and Norway, then under one crown, another; the others Germany, Russia, and the 'East Country.' The trade to northern Germany does not concern us, as it passed almost entirely through Hamburg. That with Russia had been since 1554 the monopoly of the Muscovia or Russia Company, which traded partly to Archangel on the White Sea, partly by the Baltic through the Swedish port of Narva. The East Country was served by another chartered company, the Eastland, founded in 1579 in opposition to the Hansa league. Its privileges had originally extended to Norway, Sweden, Finland, Copenhagen, and Elsinore, but the great increase of English trade to the Baltic in the middle of the seventeenth century caused them to be restricted in 1672 to the provinces between the Oder and the Gulf of Finland. Half this extent of coast belonged to Sweden, the other half to Prussia or to Poland.

The official returns of English trade with other countries for a series of years from 1697 were printed long ago by Sir Charles Whitworth. ${ }^{1}$ It appears from them that in the years 1697 to 1714 the annual value of imports from Sweden (including Finland) varied, in round numbers, from $143,000 l$. to $246,000 l$, with a mean of $182,000 l$., while the exports thither only in one year exceeded $70,000 l$., and fell in another as low as 22,000l. For Denmark and Norway the figures show an average of $76,000 l$. for imports, and, omitting 1697, of $43,000 l$. for exports. The trade with Russia varied greatly. The imports had a value of $223,000 l$. in 1704, of $29,000 \mathrm{l}$. in 1706, and an annual average of $124,000 \mathrm{l}$. The exports, nil in 1697 , rose in 1710 to $212,000 l$., with an average, excluding again the former year, of $107,000 l$. For the last three years of the period they were respectively $49,000 l$., 58,000l., and $94,000 l$. Of course the trade to Archangel is included in these figures, but in the last years of the period named as much as possible of this was diverted by the tsar's orders to his new city of St. Petersburg. The Eastland Company, lastly, imported in these years goods to the average annual value of $146,000 l$. (maximum 224,000l., minimum $64,000 l$.), exporting, up to 1708 , to the value of $137,000 l$., but afterwards, in consequence, no doubt, of the commercial blockade imposed by Charles XII upon the ports taken from him, very much less, the figure for 1710, when the blockade was first imposed and specially strict, being only $29,634 l$.

The chief exports from England to the north were woollen cloth and other textile fabrics; hardware and earthenware; metals, as wrought iron, lead, and tin; and foreign merchandise, in particular the tobacco, sugar, rice, and other produce of the

1 State of the Trade of Great Britain in its Imports and Erports progressively from the Year 1697. London, 1776. 
American plantations. The woollen manufactures reached the average annual value of $157,000 l$., of which three-fourths went to Russia and the East Country. ${ }^{2}$ The imports were the produce of the northern pine forests, pitch and tar, masts and deals ; of the mines, iron in large quantities and copper; of the fields, hemp and flax, wheat and rye; besides furs, tallow, and other articles. The hemp and flax came almost entirely from Russia ${ }^{3}$ and the East Country, the iron and copper from Sweden, the pitch and tar from Sweden, Norway, and Russia, and most of the timber from Norway. Denmark exported little but cattle to the Netherlands.

Considerable as this Baltic trade was, the economic maxims of the time condemned it as injurious. Two centuries ago the national value of a commerce was measured not by its volume, by the capital it engaged or the labour it employed, but by the preponderance of exports over imports. Money, the measure of wealth, was identified with wealth itself, and the object of commercial legislation was to increase the country's store of coin and bullion. If the imports of a trade exceeded in value the exports the natron was held to be poorer by the resulting outflow of the precious metals. To preserve the 'balance of trade' the reverse must be the case. To illustrate this we may quote the commissioners of trade in a report of 1697.4

Finding that we have imported from some countries goods to a much greater original value than we have exported thither; and it being certain that some private persons may enrich themselves by trading in com. modities, which may at the same time diminish the wealth and treasure of the nation, to which no addition can be made by trade but what is gained from foreigners and foreign countries; and that such an overbalance has not been made by any circulation in trade or exchange, so as to make such trades advantageous for this nation, as they have of late been carried on; we hove in our inquiries particularly distinguished the same from others that have a better foundation, conceiving that such trades have occasioned the exportation of coin or bullion, or hindered the importation thereof.

In the forefront of such offending commerce the commissioners place that with Sweden, the East Country, and Denmark and Norway. The evil was magnified by the fact that these countries, and Sweden in particular, made every effort to have their commodities carried in their own vessels. The report continues-

2 Record Office, Board of Trade, Trade Papers, 23.

3 The Muscovia Company brought from Archangel in the twelve months ending 1 March 0.8. 1704 6,160 tons of hemp and 216 tons of flax. The whole of the flax and 1,368 tons of the hemp were imported by one firm, Edward Haistwell \& Co. The number of the company's ships sailing to Archangel was seventy-eight, of which one was taken and six were lost (British Museum, Add. MS. 15898, f. 141).

- 'A Report concerning the General Trade of England made by the Board of Trade Dec. the 23rd 1697,' Record Office, ubi supra. 
The iron, hemp, pitch; tar, wire, masts, and deals imported from Sweden and south side of the Baltic Sea we find hath much increased upon us, and that the first cost of late years amounts to above $200,000 l$. per ann., viz.

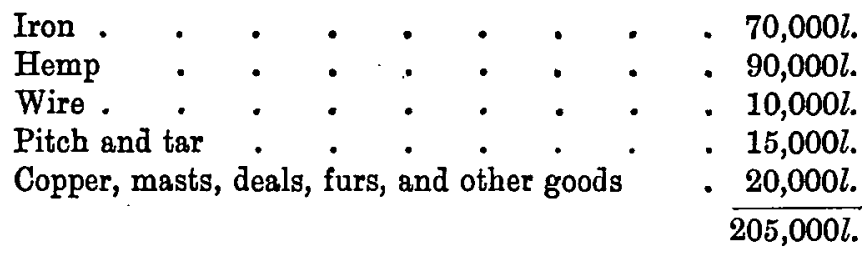

and that the ships employed of late in that trade are not above one-half English bottoms, and that the king of Sweden did about the year 1680 lay a duty of above 50 per cent. upon our woollen goods imported there, and encouraged woollen manufactures in his own dominions carried on by the help of wool from England (as we are informed), but exported thither by way-of Scotland, ${ }^{5}$ and encouraged the expense of such by the example of the court; and also having anno 1696 laid such difficulties on the English merchants, as have constrained them to leave the country, did by these means so discourage the importation of English goods that we have not exported thither the value of $40,000 l$. per annum since the laying of those duties, by which we are overbalanced about 200,000l. per ann. in goods and freight.

From Norway and other parts belonging to the king of Denmark we find the importation of timber and deal much augmented since the Fire of London and increase of buildings, and so much thereof in foreign bottoms that from Michaelmas 1691 to Micbaelmas 1696 there were entered in the custom house at.London 1,070 foreign ships from those parts, and but 39 English, our ships being charged there with some duties more than the Danes, and our exportation of goods thither not 10,000l. per ann. (those people supplying themselves with that they want chiefly from Holland and Hamburg), and therefore we are overbalanced in that trade by goods and freight at least $150,000 l$. per ann.

As remedies for this the commissioners advised that the ships called 'cats,' employed in the Norway timber trade, which alone were suitable and were built very cheaply on that side, might be naturalised as English-built ships, and that privileges should be obtained for English merchants to reside and trade in the ports of Norway.

From Russia, sey the commissioners, 'our importations, computed upon the first cost there, bave not exceeded our exportations,' and they only recommend that the Russia Company, reduced to thirteen persons, should be thrown open to all the king's subjects upon the payment of a small fine, a suggestion carried out in $1699 .^{6}$

- There being strong enactments against the exportation of wool from England.

- The fine was fixed at $5 l$. The Eastland Company had been similarly thrown open in 1672 for a fine of 2l. (Macpherson, Annals of Commerce, ii. 706, 563.) 
The measures recommended to place the Swedish and East Country trade upon a better footing were, first, that the growth of hemp and flax should be encouraged in Ireland, and the production of pitch, tar, and copper in New England, in both of which cases there would be the additional advantage of employing only English ships; secondly, that the use of English and Spanish iron should be promoted; and thirdly, that every endeavour should be made to obtain the removal of the burdens and disabilities under which the English merchants laboured.

To the first of these recommendations effect was speedily given; the Irish linen industry had already been founded by the well-known act of 1696, and to encourage importation from the North American

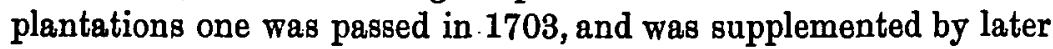
legislation of the reign. Bounties were allowed for pitch and tar, resin and turpentine, hemp, masts, yards, and bowsprits imported of proper quality. Regulations were made for the preservation of the pine forests. Among other measures may be noted the planting of a colony of Palatine refugees on the Hudson River in 1710, with the express purpose of manufacturing pitch and tar from the forests of New York. ${ }^{7}$

This sowing returned a quick harvest, at least in respect of pitch and tar. The importation of these from North America rose from 177 barrels in 1701 to 11,639 in 1714 , and 25,279 in 1715 . This was fortunate, for in the two latter years Sweden sent only 18,817 and 2,579 barrels respectively, as against 42,856 in 1704. Moreover the pitch was of excellent quality, and the first runnings of tar as good as the best of Stockholm. There came also from the plantations in 1715565 tons of resin and turpentine. Hemp, we learn, had been successfully grown, the soil being found very suitable for it; there was iron in plenty, giving satisfactory tests; and abundance of dark cypress, cedar, and pine, giving boards free from knots 20 to 40 feet long. Ships were being built as good as those launched from the home yards. ${ }^{8}$

We may apperd some statistics of Baltic imports in the years 1716 and 1717, taken from a return of $1721 .^{\circ}$ The figures denote round numbers of pounds sterling. In the latter of these years trade with Sweden was prohibited. The exports thither from England were nil, though in 1716 they had still reached the value of $24,000 l$.

7 See Calendar of Treasury Papers, 1708-14.

- Board of Trade Report, 28 March o.s. 1717, Record Office, ubi supra. Much of it is evidently based upon the 'Letter from an Inhabitant of New England,' 1715, cited by Anderson, iii. 68. Some further particulars relating to the importation of naval stores from America are to be found in the Record Office volume labelled 'Plantations, General.' In 1719, says Macpherson (Annals of Commerce, iii. 73), so much came in that quantities could be re-exported.

- Political State of Great Britain, vol. xxii. Norember 1721. 


\begin{tabular}{|c|c|c|c|c|c|}
\hline 1716 & $\begin{array}{l}\text { From Denmark } \\
\text { and Norway }\end{array}$ & $\begin{array}{l}\text { From tue East } \\
\text { Country }\end{array}$ & $\begin{array}{l}\text { From } \\
\text { Sweden }\end{array}$ & $\begin{array}{l}\text { From } \\
\text { Russia }\end{array}$ & Totals \\
\hline \multirow[t]{2}{*}{$\begin{array}{l}\text { Pitch and tar } \\
\text { Iron } \\
\text { Hemp : } \\
\text { Masts : } \\
\text { Other goods. }\end{array}$} & $\begin{array}{c}\stackrel{f}{f} \\
\mathbf{9 , 3 0 0} \\
4,600 \\
- \\
\mathbf{7 , 5 0 0} \\
\mathbf{5 2 , 5 0 0}\end{array}$ & $\begin{array}{r}£ 60 \\
700 \\
15,900 \\
400 \\
86,600\end{array}$ & $\begin{array}{r}£ \\
2,300 \\
122,700 \\
700 \\
1,200 \\
10,000\end{array}$ & $\begin{array}{r}\mathcal{E} \\
12,600 \\
300 \\
110,500 \\
900 \\
72,400\end{array}$ & $\begin{array}{r}\stackrel{£}{ } \\
24,260 \\
128,300 \\
127,100 \\
10,000 \\
221,500\end{array}$ \\
\hline & 73,900 & 103,660 & 136,900 & 196,700 & 511,160 \\
\hline \multirow[t]{2}{*}{\begin{tabular}{l}
\multicolumn{1}{c}{1717} \\
Pitch and tar \\
Iron : \\
Hemp : \\
Masts : \\
Other goods.
\end{tabular}} & $\begin{array}{r}9,800 \\
4,000 \\
200 \\
6,800 \\
64,000\end{array}$ & $\begin{array}{r}700 \\
400 \\
44,100 \\
170 \\
92,400\end{array}$ & $\begin{array}{r}7 \\
14,300 \\
-400 \\
1,600\end{array}$ & $\begin{array}{r}4,200 \\
1,910 \\
99,300 \\
6 \\
104,500\end{array}$ & $\begin{array}{r}14,707 \\
20,610 \\
143,600 \\
7,376 \\
262,500\end{array}$ \\
\hline & 84,800 & 137,770 & 16,307 & 209,916 & 448,793 \\
\hline
\end{tabular}

The third recommendation of the commissioners of 1697 had reference to the burdens imposed upon British traders to the Baltic. These were unquestionably heavy and vexatious, the Swedes naturally trying to protect their own nascent industries, to increase their revenues, and to promote their shipping interest in every possible way. The complaints of the merchants form a large portion of the contents of the British envoys' despatches from Stockholm. First of all Swedish vessels were exempted by treaty from the Sound and Belt passage duties levied by the Danes. The freedom extended not only to Swede-owned ships, but to Swedish shares or cargoes in other vessels. ${ }^{10}$ Then differential tariffs were levied in Swedish ports on the so-called whole-free, half-free, and strangers' ships, a deduction of one-third being made for the first-named class and one-sixth for the second. The result of these privileges was almost a monopolisation of the carrying trade, at least in time of peace, by Swedish shipping." F' Further,

10 See Scherer, Der Sundzoll : seine Geschichte. The exemption was obtained in 1645 and abolished in 1720.

"John Robinson, Account of Sweden, published in 1694, reprinted in 1711 and 1717. (He was secretary and afterwards envoy at Stockholm for some thirty years from 1680; he then became successively dean of Windsor, bishop of Bristol, and bishop of London, and was one of the British plenipotentiaries at Utrecht.) When Sweden was at war, he says, English ships 'had the whole employ;' but when at peace, in consequence of the differential customs, 'English bottoms cannot be used in that trade, but only while Sweden is unprovided with a number of ships sufficient for the transportation of their own commodities.' To quote from another account (of 1675) by William Allestree, secretary at Stockholm to Sir Edward Wood (Record Office, Sweden, 18, 'Regni Suecorum Status Forma ac Constitutio'). 'these impositions are very high, though they are not lay'd so much upon merchandize, as upon the shipps which bring it, which are divided into wholefree, halfefree, and strangers shipps, and accordingly pay more or lesse dutyes, except only in the case of salt, which is so necessary a commodity (I speak of Portugal salt, for they condemne all other) that whatever shipp, though a stranger, bring it, hee pay'es no more custom's in, or out, then a free Swede, during this warr.'

Elsewhere I find a whole-free ship described as 'a great ship fit for fetching salt 
there was a long array of burdens and disabilities, which may be summarised as follows from a Board of Trade report of $1710^{12}$ :-

1. By an ancient edict, revived in 1695 , foreign merchants were forbidden to stay in Sweden more than five months in the year. ${ }^{13}$

2. At Stockholm British merchants were not permitted to store salt and other bulky goods in warehouses, but were forced to sell them off the ship. Those goods which might be warehoused were placed under the city lock, and the owners could only visit them by leave. These two regulations had indeed been suspended, but might be renewed again at any time.

3. If a British ship landed goods intended for re-exportation, the usual customs were levied thereon, and no drawback was allowed for such re-exportation; nor might this be done in a different ship.

4. If a British merchant died in a Swedish town, the government thereof demanded one-third of his estate. It was no relief that merchants of other nations were similarly treated.

5. At Reval British goods could not be consigned to British merchants, but only to the burghers, who thus reaped the commission.

6. Nor could a British merchant at Reval deal in Sweden except with a burgher.

7. At Riga the British merchants were compelled under penalty to sell their salt within twenty days.

from Portugal and qualify'd to serve the king in his wars' (Record Office, Trade Papers, 23, in 'A Written Pamphlet relating to $\mathrm{y}^{\circ}$ Trade of the Baltick').

12 Record Office, Sweden. But the grievances were of old standing. We have, for instance, a similar list in July 1678 (ibid.), and an almost identical one in a parliamentary paper seemingly of $1696-9$, being concerned with the agitation for the enlargement of the Russia Company (British Museum, no. 121 in vol. xi. of the collection of tracts marked $316 \mathrm{~m}$ ).

is Robinson says two months, and further that, but for the want of capacity and capital among the Swedes to advance their own manufactures, foreigners would hardly be permitted to live or trade in Sweden at all. 'Even as the case stands, their treatment of them is as rigorous as in any country, occasioned chiefly by the envy of the burghers, who cannot with any patience see a stranger thrive among them. This is less sensible to Hollanders and others, many of whom become burghers, and the rest by their near way of living are less subject to envy, but is more especially the case of the English merchants, who find it not their interest to become burghers, and usually live somewhat too high.' Allestree writes on this point in another dissertation (September 1676, Record Office, Sweden) that it was alleged 'that our merchants' humours do by no means agree with theirs, that we are ruff and surly, and unpractis'd in those submissions which all who addresse themselves here should be endow'd with; that wee cannot brook with delays, nor attend with patience till they please to do us justice ; nor, above all, give our goods upon credit, and wait their leasure for the payment. That wee never naturalize ourselves, or take wives amongst them, or enter into any other familiarityes which msy shew wee are pleas'd with their society, or desire to live friendly with them. Whereas, on the other hand, the French and Hollanders at their first arrivall comply readily with their customes, are flexible and submissive, us'd to attendance, willing lenders and patient expectours of pay; they presently make themselves burghers, marry amongst them, encrease the number of his Majesty's subjects, and if they gett an estate they keep it here.' 
8. British merchants were not allowed to go up into the country to trade. They could not visit the ironworks or forges to see that the goods bespoken answered in quality and size to the agreement.

9. The duty on woollen cloth, half a crown a yard, was the same for all qualities. British cloth worth two shillings a yard paid as much duty as fine Holland cloth worth twelve or thirteen shillings, and this amounted to a prohibition of the importation of cloth from the northern parts of Britain. The duty was believed to be imposed in the interest of Swedish cloth, which was very coarse.

10. When the queen had no minister resident in Sweden the British there were denied the exercise of their religion.

A supplementary document gives the following further inflictions.

1. A British ship partly loaded with iron in Sweden, and then proceeding to Piga to complete her cargo, was obliged to pay duty there on the iron a second time.

2. If the iron bought stood 'in the weigh' for more than one month, double weigh money had to be paid, whereas Swedes paid only once without regard to time.

8. If goods were omitted from entry, and the master of the ship desired to make a post-entry, he was not allowed to do so, but the goods were confiscated.

4. The importation of cut or roll tobacco was forbidden.

5. Herrings and other provisions imported were not allowed to be sold till after ten days.

Merchants leaving the country, says Robinson, were sometimes mulcted of one-sixth of the gains they had made, nor were they free from forced contributions, or from having soldiers quartered upon them. New burdens were frequently imposed, and, in fine, the Swedes' treatment of the English had only reference to their own convenience. The duties imposed, wrote the British Minister at Stockholm in 1712, had for almost thirty years past amounted to little less than a total prohibition. ${ }^{14}$

Then there were monopolies. The Tar Company of Stockholm, for instance, established in 1689, refused to let pitch and tar leave the country except at its own prices and on its own ships. In 1703 it resolved not to sell them to foreign merchants at all, but only through its own factors in the different ports. It was this action in particular that brought about the American act of that year. Secure in the belief that its commodities must command the market, the company was deaf to complaint and protest..$^{15}$

If, then, this Baltic trade was only carried on, according to the

1 Robert Jackson, $\frac{7}{17}$ June (ep. 10 Feb.) 1712, Record Office, Sweden.

is Board of Trade Report, 14 Feb. 0.s. 1710, British Museum, Add. MS. 10543, 1. 200 ; Record Office, Sweden, passim. 
notions of the time, at a grave national loss, and was burdened by such heavy restrictions, why did its interruption bring first most forcible complaints and remonstrance, and then, when these proved useless, powerful fleets to protect it at enormous expense and at the risk of war with Sweden? We find our answer in the nature of the commodities imported.

It is not too much to say--indeed, we must emphasise the fact-that at the beginning of the eighteenth century the maritime prosperity of Great Britain and of other seafaring nations depended upon the produce of the Baltic regions. These were no luxuries, such as the merchants brought at great profit over the southern seas, but necessaries of the national life, the naval stores without which the ships that nourished that life could not be built or fitted. Only from those regions could these materials be obtained in sufficient quantity. Hulls might be built of British oak, but pine timber for the masts and yards, hemp for the ropes, flax for the sails, pitch and tar for their various uses, must come for the present from the north. Stoppage of the supply meant staying of man-of-war and merchantman in port. ${ }^{16}$ Liberty to prosecute the Baltic trade was vital to the prosperity of England.

So much said, we may leave commerce for politics. During the seventeenth century the political relations of England and Sweden were distinctly friendly. This might not have continued to be the case, after William of Orange had brought the former country into line against France, but for the fact that Charles XI of Sweden, guided by his new chancellor, Oxenstierna, had embarked eight years before upon a novel policy. This was nothing less than to discard the traditional alliance with France, and to seek the friendship of her determined enemy. In 1681 and 1682 Charles made treaties with Holland and with Austria. The former, signed on the very day upon which Louis XIV seized Strassburg and Casale, was the germ of the great league which was to be fatal to him. The new policy was extremely perilous, for Denmark and Brandenburg waited but the word of Louis to fall upon the defenceless Swedish provinces in Germany. But Oxenstierna carried it safely through. In 1686 Charles could go so far as to join the definitely anti-Gallic league of Augsburg.

At the same time that he made alliance with William the Swedish king had sought that of England also. As in the former interest Oxenstierna persuaded him to ratify at length the obnoxious commercial treaty concluded with Holland at Nimeguen, so he

16 If the Baltic convoy miscarried, Townshend wrote in 1715 , 'such a scarcity of naval stores must ensue as would disable his majesty from fitting out a fleet next spring upon any event' (2 Aug. o.s. 1715, British Museum, Add. MS. 28154, f. 248, and similarly as quoted by Coxe, 22 Sept. 0.s. 1716, Life of Sir Robert Walpole, 4th ed. ii. 88). 
would have granted to England a series of much-desired commercial concessions, could he have obtained thereby her political friendship. But Charles II in his last years and James after him were too dependent upon their French patron to enter into schemes to his detriment. The revolution had first to come. Charles XI sympathised with William's English enterprise, offered 6,000 men in aid, rejoiced at the early successes of the allies on the Rhine. Further troops were promised for the prosecution of the war, and if, year after year, these were not forthcoming, it was intrigue by the powerful French party at Stockholm that kept them back, not want of will on Charles's part.

He would not, however, take actual part in the war. The most urgent solicitations to this end could not move him ; he confined his interference to offers of mediation, which became irksome by their repetition. The pleas which he advanced of the exigency of the Holstein-Gottorp question, and of other hindrances, were not real. He wanted peace-leisure to complete his trenchant domestic reforms, economy to rehabilitate his shattered finances.

But for this the accord with England might not have continued, for it was sorely tried. It was a political accord, imposed upon England by William in the interests of his European schemes, but brought with it no redress of the burdens of which English merchants complained. And on their side the Swedes suffered much from incidents of the war.

Thus one of the earliest measures of the sea powers was to forbid trade with France, and they extended the prohibition to neutral ships carrying neutral goods. The Swedes were heavy sufferers, for their exports to France were important. Their vessels were often stopped by English or Dutch frigates or privateers, taken into port and their cargoes confiscated. French privateers also were about, and sometimes the same ship would be overhauled by both parties. Actual collisions too occurred, as when in 1690 seven Swedish merchant ships under armed convoy were stopped and taken by an English squadron, or when in 1695 two English frigates attacked a Swedish man-of-war. ${ }^{17}$ Charles and his ministers protested strongly, but to little purpose, against this unhandsome treatment by friendly nations, and against the violation by the Dutch of their treaty of commerce. A proposal that the sea powers should purchase the Swedish products at the price they would have commanded, had they been sold in France, came to nothing. It was only the conclusion of treaties between Sweden and Denmark for the mutual armed protection of their commerce that procured from Holland the payment of a good round sum in damages, and orders from William to his captains to refrain from a too severe enforcement of the prohibition. ${ }^{18}$

"Carlson, Geschichte Schwedens, จ. 423, 586.

10 Ibid. pp. 447,561 
In truth an alliance of Sweden and Denmark in the French interest would have ruined William's cause, and nothing was more feared by him, or desired and furthered by persuasion and bribe by Louis. More than once in the course of the war it seemed certain that such an alliance would be brought about; on one occasion the treaty for it was practically concluded. Charles himself wavered under the pressure put upon him by his ministers in French pay, but Oxenstierna stood firm. But for him the reversion of Sweden to her old alliance would have obliged William to accept an earlier peace than that of Ryswick. As the result of the chancellor's stand the friendly political relations of Sweden with England remained in 1697 unimpaired.

In this very year of Ryswick Charles XI died, leaving to his son a throne again prosperous, and the proud position of mediator to the great powers. Charles XII, a boy of fifteen, was courted on all sides. A peaceful reign seemed in prospect. The year 1698 was for Sweden a year of alliances. Treaties or conventions of various content were concluded with Holland, Hanover, Brandenburg, France, Austria, England, and Denmark. ${ }^{19}$ The young monarch and his sister were besieged with matrimonial proposals from every available quarter.

But the time of quiet proved short. Denmark had her old grievance against Holstein-Gottorp ; Peter of Muscovy was ready now to push his frontiers to the Baltic and create the empire of Russia. Charles showed which side he would take in the former quarrel when he received the young duke Frederick at his court with the highest honour, and gave him his sister Hedvig Sophia in marriage. And now another fiery youth, another Frederick, came to the throne of Denmark. Immediately the flame burst forth. Besides Peter, Augustus of Poland was ready to aggrandise himself at the expense of Sweden, and the three fell upon young Charles in concert. They did not know his mettle.

The Danish onslaught was soon repelled, for the sea powers now partially absolved their debt to Sweden by sending squadrons to the Sound in her support. These. Frederick had it in his power to destroy before the Swedish fleet could join them, but he wisely appreciated the consequences and forbore. The straits cleared of the hostile ships, Charles performed his first great military exploit, transported an army into Zealand, and threatened Copenhagen. The Danish forces were away south, across the water. Frederick, his fleet blockaded, must submit; the treaty of Travendal was forced upon him, as that of Altona had been upon his father. Sweden was rid of this adversary for nine years.

The treaty of Travendal was guaranteed by the king of England, the states-general, the emperor, the king of Prussia, and

10 Carlson, Geschichte Schvedens, vi. 57, 72. 
the elector of Hanover. In the same year 1700 was concluded a defensive treaty between England and Sweden, ${ }^{20}$ under which William bound himself and his successors to send at least 6,000 foot to the help of the king of Sweden, in case he should be attacked in his land provinces, his privileges, or his freedom of navigation or commerce. These guarantees, and this treaty, became the subject of persistent appeal by Charles XII in the days of his misfortune.

Victorious in 1700, Charles might have refrained from further fighting. Envoys from the emperor, France, England, Holland, Hanover, and Brandenburg awaited his return at Helsingborg. ${ }^{21}$ All sought eagerly his alliance, all to induce him to accept the terms of peace offered by Augustus. But he would not even hear their arguments. He was as shy of diplomatists as of women, ${ }^{22}$ and he passed on Guiscard and the rest to talk with his ministers about various inconsequent affairs, while he himself hurriedly pushed on his military preparations. He had tasted blood. Even at this age, when he had adopted a resolve, nothing could shake it; the soul of honour himself, he deeply felt the treachery of Augustus and deemed it expiable only in the field. Eight weeks after the treaty of Travendal was signed he sailed for Livonia; seven weeks later he annihilated an enormously superior Russian force at Narva. War became his mania; he regarded himself as under the direct protection of God; at eighteen years of age his military reputation was the greatest of his time.

In this same autumn the war cloud gathered once more over the west. Charles of Spain died; his will named as his heir the younger grandson of Louis XIV. Careless of the Partition treaty, Louis accepted the testament. The prospective adversaries sought to turn their treaties with Sweden to account. These were not offensive; those with England and Holland contained provision for the supply of men, ships, and money for mutual defence only, that with France but general expressions assuring friendship. ${ }^{23}$ Louis had desired that Sweden should participate in the Partition treaty; now he pressed for a guarantee of his grandson's succession.

The marquis de Guiscard followed Charles to Reval. But the

${ }^{20}$ Lamberty, i. 36 ; Macpherson, Annals of Commerce, ii. 709.

21 Carlson, vi. 154.

22 On this point see Fryxell, iv. 169, 170 (transl. Jenssen-Tusch) and the Egenhändiga Bref (Ernst Carlson), p. xviii. A Polish adherent wrote, 'Charles is Mars, Alexander, and Caesar, but Mars without Venus and love of women, Alexander without wine, Caesar without oppression of freedom ' (Brit. Mus. 580, d, 27 (8)). On the other hand the count de Croissi, who was very intimate with Charles at Stralsund in 1715 , wrote that he was 'gay de la conversation, faisant volontiers des contes sur les femmes, et est ravy qu'on loy en fasse' (Correspondance, Paris, Ministère des Affaires Etrangères).

2 Carlson, vi. 187. 
young hero was steadily bent upon the humiliation of Augustus, to the exclusion of other objects, and would not involve himself in a second war, neither would Louis grant the subsidies he asked. England sent supplies for his army, Holland advanced money; but the Swedish troops which they requested were refused. ${ }^{24}$ Either side strove in its own interest to induce Charles to grant terms of peace. Louis and William alike declared that there could be no more favourable opportunity; the emperor urged it strongly ; Augustus and Peter desired it ; the loudest in its advocacy were Charles's own ministers, despairingly aware of the insufficiency of their country's resources. ${ }^{25}$ But all for nought; Charles had the one idea fixed firmly in his head; Augustus had deceived him, and he would have his revenge upon Augustus.

During the years following this autumn of 1701 we have always the same story-fruitless court on the one side, obstinate refusal on the other. John Robinson penetrated in mid-winter to the depths of Poland ; ${ }^{26}$ English, Dutch, Austrian, and French envoys besieged Charles when he had reached Warsaw. An armed intervention was talked of. ${ }^{27}$ But all in vain: Charles would not make peace ; the western combatants could not obtain the tried soldiers of Sweden to fight their battles. It became the main object of the allies to prevent the extension of the northern war into Germany, for, should Saxony or Pomerania be endangered, they feared the withdrawal of German troops from Italy, from the Rhine, and from the Netherlands to defend their own frontiers. ${ }^{28}$ Terrible apprehensions on their side, great hopes on that of France were roused when Charles in $\mathbf{1 7 0 6}$ invaded Saxony, and when in $\mathbf{1 7 0 7}$ he seemed to be on the verge of war with the emperor. Marlborough himself travelled to Alt-Ranstädt to exercise upon the conqueror those acts of diplomacy of which he was as great a master as of war. Great was the relief at London, at the Hague, and at Vienna when Charles at length, believing Augustus crushed, Poland secure, departed to attack the remaining Russian in his own territory. For two years the allies were freed from the menace of the northern meteor.

"2 Carlson, vi. 190. 25 Ibid.pp. 215-6. 26 Early in 1703. 27 Noorden, i. 221.

23 Marlborough in 1709 estimated the Danish, Saxon, and Prussian troops serving under him at 40,000 men, and those of Hanover and Holstein-Gottorp at 20,000. All these he feared might be withdrawn should Saxony or the German provinces of Sweden be invaded (Coxe, Life of Marlborough, iii. 123).

In May 1712 the foreign troops in English pay in the Netherlands, who refused to obey Ormonde's orders, were 6,260 Danes, 10,400 Hanoverians, 8,737 Prussians, 5,912 Saxons, 3,965 Hessians, and 701 of Treves. Besides these there were 2,000 Palatines in garrison at Maestricht; 2,442 of Münster, 807 of Osnabrück, and 797 East Frisians were in Dutch pay ; and 1,441 Holsteiners, 1,300 of Saxe-Cotha, and 581 of Walef's regiment of Liège cuirassiers retired with Ormonde-a total of 45,343 (British Museum, Add. MS. 10453, f. 356). And other hired German troops were serving the allies in Italy and Spain. 
In 1709 we enter upon the second period of Charles's career, the period of defeat and exile, which served the more to exhibit his unconquerable resolution. We lament at the same time his utter disregard of his country's welfare and admire the inflexible courage which crushed misfortune. Not long after the battle of Poltava he could write to his sister: ' Here all has gone well. Only at the finish, only by a particular accident, we happen by a misfortune in arms to have had a loss, which I hope will shortly be repaired.' ${ }^{29}$ For more than five years he dictated the foreign policy of Sweden from a Tartar town on the remote Dniester, or as a prisoner of the sultan in Turkey. During all that time he presented the same unquenchable spirit and unchanging purpose. An ordinary man in his position would have been glad to compound with his adversaries, by abandoning something to regain most, and make a fresh start. Of opportunity there was plenty; the nations grew timorous of the rising power of the tsar; Augustus more than once proposed conditions of peace, Frederick of Prussia advantageous terms of alliance; Peter himself was disposed to secure his conquests by a treaty. But Charles would give up nothing-not a foot of Swedish ground, not a single privilege, not even the sovereignty of Stanislaus, which that unforiunate himself desired to resign. Only to the humiliated Dane would he grant peace, he to request it. ${ }^{30}$

From the course thus marked out no persuasion on the part of friends or ministers could induce Charles to swerve. Their efforts to do so only made him the more obstinate. The mere suspicion of compulsion was odious to him, and would drive him, pig-like, in the opposite direction, ${ }^{31}$ a foible well known to and utilised, it was believed, by his enemies. Advice with him was dictation, and dictation was that which, after eceit, he most abhorred. Firmness might be folly, concession necessary and

20 Bender, 9 Aug. 0.s. 1709; Egenhändiga Bref, p. 97. See also the remarkable passage in his despatch to the 'Commission of Defence' from Otchakov, 11 July o.s., ibid. p. 363 .

${ }^{30}$ There is a special work by F. F. Carlson on the peace negotiations of Charles after Poltava, Om Fredsunderhandlingarne åren 1709-18, Stockholm, 1857. He duly calls attention (pp. 4, 27, 38) to the disadvantage of Charles's attempt to direct affairs from so great a distance. By fast travelling Vienna could be reached from Bender in about three weeks; but the journey usually took a month, and another fortnight or so was required before the courier could reach Vellingk at Stade. Despatch and answer therefore required a period of at least three months, and in that time the face of affairs would be completely changed.

"For example: 'Vous connoissés le Roi, et vous savés, que vouloir empecher une 'chose, ou la lui defendre, est lui en donner l'envie \& l'y obliger' (Fabrice to Goertz, 24 Dec. o.s. 1710); - ' He thinks he has been neglected by the Allys, who instead of assisting in his missfortunes have taken occasion to prescribe him laws; this is what he can't bear' (Jefferyes, 15 June 0.s. 1711, Record Office. 'Though Jefferyes was accredited to Charles XII, his despatches are preserved in a Poland volume, because he first joined Charles in that country). For Fabrice see below, p. 694, n. 50.

roL. XVI. - NO. LXIV. 
wise; but in such wisdom he scented dishonour, and to preserve his honour he would, and did, sacrifice all else.

No sooner was the catastrophe of Poltava known than Augustus grasped again at the crown of Poland, while Frederick of Denmark hurled an army upon the. Swedish mainland. The troops which Charles had left in Poland under General Krassow retreated into Pomerania, menacing the neighbouring countries with hostilities and the plague. The treaties of Travendal and AltRanstädt were torn up, and it seemed inevitable that the flames of war should now cross the frontiers of the empire.

To consider what should be, done in the emergency, the allied powers contending against France assembled a conference at the Hague. As the outcome of negotiations conducted and resolutions of the states-general passed during the winter it was proposed to establish a system of neutrality; the Swedish army in Pomerania to remain there inactive, while the confederates in return should agree to attempt nothing against that province or the duchy of Bremen. To Frederick and Augustus this scheme was quite acceptable. The former, indeed, and the tsar helped to forward the negotiation. The Danish invasion of Scania had been ignominiously repulsed, reprisals were feared in Jutland.and elsewhere. Augustus was living in terror of an irruption by Krassow into Saxony. The two signified their adhesion, and the government at Stockholm did the same from sheer necessity. ${ }^{32}$ A convention, embodying the agreement, was signed at the Hague by the sea powers and by Austria on 31 March 1710. Force was to be employed, if necessary. ${ }^{33}$

This famous convention, if carried out, might have saved for Sweden her German provinces; but it gave her no protection elsewhere, and deprived her of the power of counter-attack. It cannot be denied that the allies, in making it, were less solicitous for her welfare than for the maintenance of peace in the empire, in order that they should retain in their service the full number of the Danish and German contingents. This was natural enough, in view of the magnitude of the interests involved. Lord Stair from Dresden urged most strongly upon his government the necessity of protecting Saxony..$^{34}$ A treaty of defensive alliance even with

3: Gyllenborg, the Swedish minister in London, was urgent in representing the miserable state to which Sweden was reduced, and in expressing the hope that England and Holland would not abandon her. One long memorial from him about this, and on the dangerous increase of the Russian power, is dated 20 April o.s. 1710 (Record Office, Sweden). Jackson, the English resident at Stockholm, came to London at this time on a special mission to represent the same to his government. The original letter which he brought from the Stockholm regency, dated 18 Feb. 0.s. 1710, is preserved at the Record Office (Sweden, royal letters).

${ }^{33}$ For the documents see Lamberty, vols. v. vi.

"1 Record Office, Polnnd; and to Robethon, British Museum, Stowe MS. 223 (first months of 1710). 
Great Britain was discussed there. Marlborough wrote to Stair that the three great powers were 'unanimously resolved to maintain' the electorate of Saxony ' against any aggressor whatsoever.' ${ }^{35}$

Yet it had been well had Charles accepted the convention. The war would then have been confined to his provinces east of the Baltic, and these, or at least their ports, his navy might have saved. But in his view the guarantors of the treaties of Travendal and Alt-Ranstädt ${ }^{36}$ were bound to protect not Denmark or Saxony from him, but his German provinces, and indeed all his dominions, from them. It was true that they could not with the best of will, involved as they were to the utmost of their resources in the French war, carry out their guarantees; that his lust of war had made these in fact obsolete: That did not matter. Promises with him required performance. If the allies would not fulfil their undertakings they had perjured their troth and must accept the consequences. In due course he would have vengeance.

The threat was by no means idle. It is the fact that Charles at Bender was not less confident, and little less feared, than Charles at Warsaw or in Saxony. He did not at first, it appears, intend to remain in Tartary, but, as soon as his wounded foot was healed, to make a dash to join Krassow in Poland. From this design he was diverted partly by Krassow's retreat and partly by expectations held out to him of escort homewards by a Turkish force. It does not seem that there was any sincerity in this proposition, but that the intention was to keep Charles in hand and play him off against the Muscovite. ${ }^{37}$ But he took the pashas at their word, regarded their hints as promises, and stayed to insist on their performance. ${ }^{38}$ It was fully expected in Christian Europe, and by Charles himself, that he would shortly reappear in Poland at the head of an irresistible array of Turks and Tartars, ${ }^{39}$ to impose his will on foes and friends alike.

8s 1 April 1710, Despatches (Sir George Murray), iv. 707.

26 Augustus promised by art. 21 of the latter treaty to obtain the guarantees of the emperor, the queen, and the states-general thereto within six months. These, if never formally obtained, were promised and regarded as given. See the quotation from Bolingbroke's despatches, 5 Dec. o.s. 1712, below, p. 699, n. 64.

"Carlson, op. cit. p. 9 ; Bir Robert Sutton, 1 Oot. o.s. 1710, Record Office, Turkey; Fabrice to Goertz, 15 Dec. o.s. 1710.

${ }^{28}$ In the same spirit as is described by Fabrice later (31 Jan. 0.s. 1713): ' Ce Prince qui se pique de tenir la parole qu'il donne, prétend qu'on en use de même à son égard, et ne veut entendre parler d'aucun temperament; c'est là ce qui nous a retenu depuis si longtems en Turquie, et me fait craindre que nous n'en sortions pas encore sitot.'

20 Sir Robert Sutton, British ambassador at Constantinople, wrote that besides Charles's Swedes, Cossacks, Wallachs, and Poles, 10,000 Turks and a great body of Tartars would follow him into Poland (16 Nov. o.s. 1710). Later these forces were magnified in public report; 80,000 janissaries and spahis and 40,000 Tartars were by one account to be expected (Jackson, from Stockholm, 25 March (4 April) 1711, Record Office, Sweden). $\mathbf{8 0 , 0 0 0}$ was the number given by Poniatowski in February 1711 (Jefferyes, 20 Feb. 0.s.) 
Staying on then, Charles did his utmost to stir up the sultan to make war upon the tsar! The Turks themselves from the sultan downwards, ${ }^{40}$ we learn, were anything but desirous of war. But the Muscovites had a bitter enemy in the neighbour on whose country they were constantly encroaching, the Tartar khan, and he zealously advocated Charles's cause at Stamboul. Three times, while the latter was at Bender, was the desired end attained; three times did the crafty Russian baulk his rival's hopes. During two and a half years European politicians watched with anxiety the alternating states of peace and war. The French ambassador at Constantinople, Des Alleurs, worked hard in the latter interest, and even hoped for a rupture of the peace of Carlowitz. On the other side Sir Robert. Sutton and his Dutch colleague, Count Colyer, made strenuous efforts to preserve the peace. As the hostilities began and ceased, reopened and ceased again, so waxed and waned the terror of Charles's return, so were the western allies uneasy or content, the king of Denmark inclined to or averse from terms, Augustus and Peter anxious or indifferent to see the neutrality enforced.

Long before Charles heard of the convention-the day, in fact, after it was signed-he sent to his home government orders that no terms were to be made without his knowledge. This news reached the allies in June 1710. It disquieted them wofully, for it meant that Charles would not recognise the act of neutrality, and that Krassow might assume the offensive. Not that the latter's troops were really dangerous; badly equipped, plague-stricken, and halfstarved, they were good for little more than to garrison the towng of Pomerania and guard its frontiers. But they were veteran and used to victory; the fears of Augustus magnified their strength; the Danish defeat at Helsingborg had opened the prospect of reinforcements to arrive from Sweden. Proposals to hire them, or a part of them, for the service of the allies failed, for Charles sent word that he required them for his own purposes. Frederick and Augustus, even with Peter's help, had not forces at home sufficient to resist them; they would have to recall the battalions so much required in the Netherlands. The signatories to the convention feared an immediate irruption into Poland or Saxony, and felt themselves obliged to give effect to that clause thereof which provided for the use of force. On 4 Aug. ${ }^{41}$ a supplementary convention was signed, prescribing the contingents to be furnished by England, Holland, and Austria, as well as by Prussia, Hanover, and other consenting states, to form a force which should hold Krassow in check.

But as the weeks went on, and Charles's affairs seemed not to

to Sutton, 29 May 0.s. 1711 ; and similarly, 12 Jan. 0.s. 1712, 20 Jan. o.s. 1713.

1 Not 4 May, as Erdmannsdörffer, ii. 310. 
prosper at the Porte, the necessity of assembling this 'neutrality corps' became less urgent. That the trouble and expense of its collection need not be incurred was held particularly by the new British government. St. John, secretary of state for the northern province, rebellious from the first against interference in continental affairs, gare expression to this opinion. "They will not find it easy,' he wrote, to persuade us to comply in this affair, who have so much on our hands already. ${ }^{{ }^{4} 2}$ He sympathised with Sweden in her misfortune; it was not, he confessed, to the interest of England that she should be ruined for the benefit of 'the Muscovite and the Pole,' but that a proper balance of power should be maintained in the north. ${ }^{43}$ Townshend at the Hague concurred, and advised that the Danes should rather be repressed, threatening as they were to take up winter quarters in Holstein. ${ }^{44}$

But towards Christmas time came startling news from Constantinople. Charles on hearing of the convention had been angered in the extreme, and had absolutely refused his consent. $\mathrm{He}$ had besieged the sultan with increased vehemence, and had been successful ; the horsetails had been set up early in November, and war declared upon the tsar. On the last of that month Charles signed his famous protest against the convention, threatening with his vengeance all and every who should oppose his designs. 45

The northern confederates did not await the arrival of this document to renew their urgent solicitations with the allies, who fully realised the danger. ${ }^{46}$ Alarmist reports of the Turkish

12 To Lord Raby at Berlin, 24 Oct. o.s. 1710 (Record Office, entry books, Prussia).

is Cp. to Marlborough, 10 Nov. o.s. 1710, ibid. Holland; a despatch of great length upon the affairs of the north.

47 and 31 Oct. 1710 , ibid.

15 'Quod si autem praeter omnem spem et exspectationem quisquam amicum animum exuens remoram aut obstaculum ipsi objiceret, tum cum in eo fuerit, et justis armis ipsi sit persequendus conjuratus hostis, declarat Sua Regia Majestas se non posse eundem alio quam aggressoris loco habere.'

40 We may quote St. John to Palmes at Vienna, 29 Dec. o.s. 1710, Record Office, entry books, Germany: 'The Rupture of the Turks, and their attacking Muscovy or Poland, would not have any great or immediate influence on our affairs were we well secured from any Enterprize on the side of Pomerania. But that is the capital point at present, and ought to be fenced against with the utmost precaution, since the King of Sweden has openly avowed his dislike of the Neutrality, and at the same time increased his Troops to a considerable number. These steps leave no room to doubt of his intentions, when he shall have an opportunity of employing that Corps. And therefore as the danger seems to be very imminent on that side, the remedy ought to be applyed both very quickly and effectually. You may be sure that ber Majts is not willing to engage in another Warr, or draw herself into the Quarrells of the North. But if the Empire should be embroiled, there are so many inconveniencys that will apparently ensue, that there seems to be no way of aroiding them, but by putting it out of the power of the King of Sweden to disturb the Neutrality from that Quarter. We would rather see this done by the Princes chiefly concerned, than have an immediate hand in it ourselves. But it is agreed that some timely and effectuall 
intentions reached Vienna, ${ }^{47}$ and infected the Hague and London. St. John was fully persuaded that. Charles meant to attack the empire in concert with France-he from Pomerania, Louis on the Rhine. ${ }^{48}$ All recognised the necessity of immediately assembling the neutrality corps, and set themselves in earnest to do so. But they failed. It was hard enough to procure troops for service against France; now some 20,000 men were to be found for an independent object. For all his efforts Marlborough remained short of three battalions to complete the contingent to be paid for by England. Equal difficulty was experienced in providing the other quotas. The place of rendezvous could not be fixed; some were for the frontier of Holland or Holstein, some for the Pomeranian, others for Silesia. The command of the force was in dispute between George of Hanover and his son-in-law, the prince royal of Prussia. One much-discussed expedient was to employ for the purpose, under the command of Augustus himself, the Saxon troops engaged to the allies; but the various forms of this idea were finally rejected as inconsistent with the scheme of the neutrality. ${ }^{49}$

We may present here a brief review of Charles's present estimate of his position, from the despatches of Frederick Ernest de Fabrice, who was sent by the administrator of Holstein-Gottorp to attend him at Bender, and who was further charged with instructions from the elector of Hanover. ${ }^{50}$ As the envoy of a closely allied state, and in constant communication with Charles both in public and in private, Fabrice had exceptional opportunity of observing him.

measures must be taken to prevent the recalling of Troops from the Service of the Allys, and quiet our apprehensions on that side.'

1 Palmes to St. John, 20 Dec. 1710, Record Office, Germany.

48 For instance, to Wich, 23 Jan. 0.8. 1711 ; to Peterborough, 13 Feb.; and to Palmes, 20 March, ibid. entry books, Hamburg and Germany. To Peterborough St. John wrote of the combined attack by Sreden and France as 'the scheme which there is no room to doubt has been concerted between them.'

4. See Townshend's despatches from the Hague of January and February 1711, and those of St. John to him, and to Raby at Berlin (Record Office, Holland and Prussia). If Augustus, wrote St. John, would recall his troops definitely from the pay of the allies, good; the latter would be able to allege this as cause for not marching their contingents, and would hand over the responsibility of repressing Krassow to him. But Augustus, he said, knew better than to take that measure, as he wished to have the allies engaged in hostilities with Charles (to Townshend, 30 Jan. 0.8. 1711).

so Fabrice, to whose despatches we have already referred, was the second son of Weipart Louis Fabricius, an old minister of the duke of Celle; by birth therefore a subject of the elector of Hanover. His despatches to the administrator and his minister Goertz have been printed as Anecdotes du Sejour du Roi de Suede a Bender (Hamburg, 1760). I use here an unpublished despatch to Bernstorff of $25 \mathrm{March}$ 0.s. 1711, a copy of which was furnished to the British government (Record Office, Sweden). Despatches of the end of December 1710 to Bernstorff and to Goertz are of similar effect; an extract of the former by Robethon.is at the British Museum

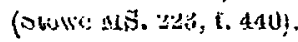


Charles piqued himself, he says, upon his promise not to interfere in the affairs of others. He would not brook the slightest menace ; menaces and danger but whetted his desire to brave them. In his past conduct he had never given any sign of a desire to aid France; the contrary was the case. But the allies, guarantors of the treaties of Travendal and Alt-Ranstädt, had limited their efforts in his behalf to remonstrance. Charles had reminded them of their duties, but only the elector of Hanover had thought fit to explain in return the reasons of his inability to perform them. The allies had sent no envoy to Charles. They had recognised Augustus as king of Poland. They had set on foot a scheme of neutrality, of which the first end was their own interest, and only the second, or perhaps one of several, to preserve the German provinces of Sweden. So far from aiding Charles they had moved beaven and earth to foil his efforts to rouse the Porte. When these had been successful they asked for assurance that he would not disturb the empire. But they had given no assurances in his favour in return, and he demanded as much consideration at Bender as in Saxony. The Turkish war was not directed in any way against the empire, nor against the republic of Poland. It was only desired to reduce the power of the tsar, daily becoming more redoubtable. Indeed, the mere suspicion that Charles meditated injury to the emperor or his allies was offensive to him. If the allies desired further assurance, they must send to Charles able ministers to convince him of their good intentions. The most essential token that they could give thereof would be to force a peace upon Denmark ; ${ }^{51}$ in regard to Augustus they might offer their mediation. If they sent a force to prevent Krassow from entering Poland, within a year, Fabrice thought, they would see Germany in flames.

The offer of the elector of Hanover of a loan of 250,000 crowns to secure the safety of Bremen and Verden Charles took as a mark of friendship. But to avoid misunderstanding he had ordered the government at Stade to accept money only from private persons, and for the same reason had declined a similar offer of 200,000

31 This, Fabrice insisted, was 'le grand Article.' Sir Robert Sutton too wrote that this peace 'would be the greatest obligation the queen and states-general could lay upon his Swedish majesty' (Record Office, Turkey, 12 Feb. o.s. 1711). Indeed, the advantages to be gained from it were too obvious for even Charles to overlook. The troops employed in watching the south coast of Sweden and the Norway frontier would be set free for service across the Baltic. The fleet might be greatly reduced. Commerce would be relieved. Krassow could break into Poland, relieved of the fear of invasion from north or west. The enterprise of the Turks would be sensibly aided (Carlson, p. 16, note, from a memorial by Müllern). Charles would not, perhaps, have considered the matter had not his pride been gratified by the defeat of the Danish forces in the field. As it was, he instructed the senate to arrange terms with Denmark as soon as he heard of the victory of Helsingborg (26 April o.s. 1710, Egcnhindiga Bref, p. 365). 
crowns from the administrator of Holstein-Gottorp. An alliance with Hanover, he said, would always be preferred to one with Prussia.

Here then was a defeated exile, not crushed or desponcient, but confident of his powers and resources, demanding, not praying, dictating rather than accepting terms. ${ }^{52}$ What to reply to his demands, or what to do at all, the allies frankly did not know. The British government tardily sent to Bender Captain James Jefferyes, who had attended Charles in his last campaign, and had been taken prisoner at Poltava. But he could not be heard from for months; leaving in January, and staying on his way at the Hague, Hanover, and Vienna, he did not reach Bender till 28 April. And now, at the beginning of March, Charles's protest was formally presented at the Hague, with the specific demand that the conditions of the peace of Travendal should be restored, and the declaration that, if that could not be done, the guarantors must excuse the measures which he should take. ${ }^{53}$ St. John in his despatches gives full expression to the embarrassment of the British government, its disgust at the way in which the Dutch had managed the neutrality - for to them, he insisted, the conduct of that business had been left-and his own ignorance of what course to advise. ${ }^{54}$ 'Every measure that occurs to one's thoughts,' he wrote, 'is immediately attended by a crowd of objections; and yet the necessity of resolving on something presses us very hard.' To force a peace upon Denmark would be to quarrel

with those northern powers who are at present our certain friends, and whose troops are employed in our service against the common enemy, and that in favour of a prince who is a very uncertain friend to us, and from whose troops we have many just apprehensions of disturbance, without the expectation of any assistance.

Augustus, ' a good ally,' and Peter, could not be abandoned to Charles's fury. ${ }^{55} \mathrm{~A}$ 'trimming dilatory game' was the only one that could be played.56 A truce in regard to the empire had been proposed, and if that were accepted, 'whether the peace succeed

32 Very instructive as to Charles's defiant confidence is his despatch to the senate of 3 Feb. o.s. 1711, absolutely refusing any accommodation witb Russia, and insisting upon uncompromising resistance (ibid. p. 369)

53 Townshend, 3 March 1711, enclosure, Record Office, Holland.

5. See to his Amsterdam confidant, John Drummond, 27 April, printed by Gilbert Parke; and in the Record Office entry books to Marlborough, same date, and to Raby, 24 April, 18 and 22 May (Holland), and to Whitworth, 8 and 18 May (Prussia), all old style.

35 To Raby, 24 April o.s. ibid. It was not likely, St. John banteringly remarked, that Charies would admit Peter to a peace on any terms, ' since in that case he would have no Enemy left at all; and to have always one seems to be an article very essential to his happiness.'

so To the same, 22 May o.s. 
or not, we shall have consumed the summer, and shall be got over the crisis of our present distemper.' 57

But of a truce Charles would not hear. The Danes, said Gyllenborg, had been beaten, Augustus was not to be feared, the Muscovites had conquered all they could. A cessation of arms would oblige Charles to keep his army starving in his own devastated provinces. It would deprive him of the fruits of his efforts at the Porte, and be of advantage only to his enemies..$^{58}$

In the meantime the desire to aid Sweden was growing in England. To a natural sympathy with the losing side was added the consciousness that it was not to the interest of the one country to witness the destruction of the other. The apprehension of what Charles might do was being allayed. Whitworth, on whose advices St. John particularly relied, reported that the Swedes in Pomerania were not really to be feared, and that an outbreak on their part was much less to be expected than an attack upon them by the confederates. ${ }^{59}$ The chances too of the Russians in south-eastern Europe were just now preferred to those of the Turks. ${ }^{60}$

But at length, on 8 July o.s., Jefferyes's first despatch reached London. He had been instructed on three points-to obtain Charles's consent to the neutrality convention, to discover whetber mediation by the queen and her allies would be accepted, and to obtain the revocation of the commercial blockade imposed by Charles upon the ports which Peter, reaping his harvest, had lately taken to himself. He was forced to report that neither to the allies nor to England separately would Charles yield anything. The convention, he said, had been made without his knowledge, and was of advantage to his enemies rather than to himself. As to mediation, the queen was bound by treaty to compel the Dane and Saxon to make peace; negotiation with the tsar was the business of the Porte. The blockade must and should be maintained, as long as Peter held the ports in question.

This plain uncompromising refusal dispelled any remaining hopes of accommodation. Charles would not accede to the proposals of the British government; it could not give effect to his demands. His inflexibility riveted the fetters of the French war. St. John branded bis conduct in reference to the blockade

s7 To Whitworth, 8 May o.s. Whitworth, accredited to the tsar, had written on 14 May from Hanover: 'If time can be gained till next winter the allies will certainly then have a better prospect of turning the whole affair' (Record Office, Russia).

ss 5 June 0.s. 1711, Record Office, Sweden.

so From Berlin and Dresden, May and June 1711, ibid. Russia.

$\infty$. The Muscovites are, without dispute, in greater forwardness than the Turks, and the king of Sweden in, little condition to support that fierte which he put on when he protested against the act of neutrality' (St. John to Marlborough, $10 \mathrm{July}$ o.s. 1711, Gillbert Parke). 
as 'groundless and intolerable,' and talked of force. ${ }^{61}$ He vented his spleen by denouncing in scathing terms the whole northern policy of the allies from the treaty of Alt-Ranstädt. ${ }^{2}$ His government at length consented to, or rather declined to dissent from, the invasion of Pomerania, a formal resolution as to which was adopted at the Hague on 14 Aug., ${ }^{63}$ and which itself at once took place. Before the end of the month the Saxon army, allowed by the king of Prussia to traverse his dominions, crossed the Tollense to Demmin, while the Danes attacked the northern fortress of Dammgarten. The neutrality convention was a dead letter.

In the same month changes of the first importance occurred elsewhere. In the Netherlands Marlborough performed the impossible, passing in the face of the superior army, which Villars dared not risk, the lines which both generals had deemed impregnable. From Turkey came the news of Peter's marvellous escape on the Pruth, of the treaty he had procured, and of the ruin, not indeed of Charles's hopes, but of any immediate prospect of their fulfilment. Marlborough's success, and subsequent capture of Bouchain,

a) To Drummond, 3 Aug. o.s. 1711, Gilbert Parke; Jackson from Stockholm, 14 (24) July (Record Office, Sweden).

${ }^{82}$ To Whitworth and Marlborough, 12 and 10 Julg 0.8. 1711, Gilbert Parke. In further illustration of St. John's mind in regard to the Swedish war at this time we may quote a despatch to Marlborough of 20 July o.s. (Record Office entry books, Holland): ' I would speak to Your Grace concerning the situation of the Northern affairs, but they are now come to such a pitch of distraction, the demands made upon us by both sides are so high, and so peremptory, every expedient which can be thought of is lyable to so many objections, in short it is so dangerous to the common cause to do anything, and so impossible to do nothing, that her Majesty and all those who have the honour to serve her, are at a loss what measure to take upon the Resolution which the States-Generall are come to, and have transmitted hither. The only Ouverture they seem to have thought of, through which to extricate themselves and us from the present difficalty is, a proposition that the Sazon Recruits should continue where they are, and that these Forces with the Corps of Neutrality should stand by, whilst the Confederates of the North do, by a very gross connivance on our part, march into Pomerania, and attack the army of Sweden, in which case the States hope that these Princes will go no further than barely to deliver themselves from the apprehension which they are under of that Body. Your Grace sees how little likely it is that King Augustus and his allses will exert much moderation in their success, and how destructive it may prove of the Ballance of Power in the North, and of the Protestant interest in Germany, if those provinces of Sweden should be subdued and parcelled out. . . . The Dutch have had the whole conduct of this affair; if they get as well out of it, I shall have a great opinion of their ability or of their luck.'

And similarly to Orrery, 24 July o.s. ibid.: "To enter into an actual Warr with Sweden, either by employing the Corps of Neutrality, or by paying the Saxon troops whilst they are employed according to the desire of King Augustus, is contrary to the inclination of all our Ingagements. On the other hand to stand by and behold the Destruction of Crassau's army, and the conquest of Pomerania, has something very mean and cruel in it.' See also to Dayrolle and Orrery, 10, 13, and 17 July o.s. ibid.

whe articles are given by Lamberty, vi. 468. St. John wrote of the 'expedient:' 'It is a pretty considerable stretch for Neaters to take, and nothing but the King of Sweden's obstinacy, which made it necessary, could render it tolerable ' (to Whitworth at Vienna, 28 Aug. 0.8. 1711, ibid. Germany). 
might, under the late whig government, have opened the road to Paris. For a ministry intent upon peace they smoothed the way to Utrecht. Preliminaries were actually signed in October. But eighteen months were to elapse before the peace was an accomplished fact. Denain was needed to convince the Dutch that, as England had made up her mind to retire from the war, they must do the same. During those long months of negotiation the British government continued to plead the exigencies of the war as an excuse for standing a spectator of the northern tragedy. The dismemberment of Sweden went on apace, regardless of its yea or nay. ${ }^{64}$

Peter the Great now becomes the leading actor in the drama. His troops formed the backbone of the confederate army, he alone could wring from reluctant subjects the money which was more necessary than men. Credited on his return from Turkey with the widest designs of conquest, the allies were conscious that they could not baulk him. He was known to be gravely incensed with the court of Vienna on several counts ; it was believed that he had arranged a definite treaty with France. To conciliate him the British government took great pains. Whitworth was at length able to meet him at Carlsbad in October 1711, and followed him to St. Petersburg, where he remained in attendance for several months. Already in November he was able to send home reports of a reassuring character in regard to Peter's relations with Vienna and Paris, but that was the limit of his success. He failed to detach Augustus from the Russian alliance, ${ }^{65}$ or to obtain more from Peter than assurances of goodwill and satisfaction, even when in May 1712 the news arrived that the efforts of the British and Dutch ambassadors at Constantinople to obtain for him a peace had been crowned with success. Peter steadily prepared his armaments, built ships, impressed men, and levied contributions. In June he set out in person for the scene of war before Stralsund. It was

64 During the whole of $1712 \mathrm{St}$. John, who became in July Viscount Bolingbroke, harps in his despatches on the necessity of making peace with France before attempting to interfere in northern affairs. The queen, he wrote to Breton at Berlin, must delay interference in the affairs of the north till peace was concluded. She had her hands tyed up from medling in them more perhaps than any other power in regard to her former engagements.' The treaty of Travendal obliged her not to favour the king of Denmark, and that of Alt-Ranstädt, the promised guarantee of which was 'in justice as obligatory as if it had been actually given,' not to espouse the interest of Augustus. On the other hand 'nobody but his Swedish Majesty would imagine, that in the present posture of affairs any scheme of Peace can be entered upon, wherein greater regard will not be had to King Augustus, and the King of Denmark, than is stipulated by those Treatys. One advantage we have however resulting from this misfortune, that we are furnished with a good excuse for keeping our selves at present from medling at all ' (Record Office entry books; Prussia, 5 Dec. o.s. 1712). Cp. other despatches to Breton, and to Scott at Dresden and Pulteney at Copenhagen, ibid. Pcland and Denmark.

is See the arguments used in his despatch of 4 March o.s. 1712, ibid. Russia. 
clear that he would follow his own ambitions, and none knew what limit he might set to them. That he was not inclined to favour British trade was evident from the failure of. Whitworth to obtain redress for the hardships of which the merchants complained, or to push to a successful issue the negotiations for a treaty of commerce. .66

The kings of Denmark and Poland were not in a position to demand similar consideration. Loans which the former obtained from Hanover were stopped when his predatory designs upon Bremen became manifest. Neither could get money from England when their troops were no longer required to fight against France. St. John, in his anger that those whom the queen paid refused to obey her orders, following Eugene instead of Ormonde, not only notified that no further sums would be forthcoming, but threatened confiscation of arrears. He had already given vent to expression of the grievances of his government against the two kings. The former had been guilty of 'flagrant injustice' in seizing as Swedish ships vessels bought by Englishmen in Sweden. Augustus had long offended by his slackness in supplying the stipulated troops, and by his continual threats of withdrawing those that had arrived. ${ }^{67}$ The British government had neither need nor desire to consult their interests.

In the autumn of 1712 a fresh phase of the northern war opened. Stenbock, the victor of Helsingborg, arrived from Sweden, and shortly smote the Danes once more at Gadebusch. The next months were occupied with his retreat into Holstein, his vicious resistance against overwhelming odds, and his final surrender. Sweden lost her last army. Its disappearance was followed in the summer of 1713 by a third and final peace between the sultan and the tsar.

The advent of Stenbock determined the emperor to endeavour afresh to enforce neutrality in the north of Germany. A congress of the powers most nearly interested, Prussia, Hanover, Wolfenbüttel, Hesse-Cassel, and Münster, assembled at Brunswick in December 1712 under the presidency of Count Damian Schönborn. A résultat of its deliberations was quickly arrived at and made known. ${ }^{68}$ It was distinctly hostile to Sweden, Stenbock being regarded as the

\footnotetext{
${ }^{60}$ On all these matters see Whitworth's despatches, loc. cit. He followed the tsar to Pomerania, and after spending the autumn at Berlin returned home. A detailed list of the merchants' grievances will be found in a memorial by his successor, George Mackenzie, 10 March o.s. 1715, ibid.

a: See St. John's despatches to Marlborough and Strafford, autumn of 1711, ibid. entry books, Holland.

is Printed by Lamberty in summary viii. 295, and in full viii. 324. He is confused, attributing the former to a conference at Hamburg. A copy at the Record Office (Sweden) is dated $\frac{20}{30}$ (Swedish stgle, that is) Dec. 1712. The congress, Robethon wrote to Grote in England on 16 Dec. 1712, was to meet next day (Brit. Mus., Stowe MS. 224, f. 323).
} 
aggressor. The powers named, and the elector Palatine, were to send across the Elbe a force of 20,000 men; the combatanis were to be summoned-the Swedes in strong terms, the tsar avec menagement-to retire beyond the frontiers of the empire within three weeks, the former across the sea ; in case of the defeat of either side the neutral force was to be used against the victor. But these were words only, for the fears and jealousies of the deliberating powers prevented any effect being given to their resolutions. ${ }^{69}$ The landgrave of Hesse-Cassel, the marriage of whose son to the princess of Sweden was already in prospect, was in particular blamed for the failure. Separating in March 1713, the congress was summoned afresh for the following December. But the members were tardy in assembling, and their consultations void of result. It was still sitting when George of Hanover became king of England.

The year 1712 had seen the temper of Charles towards England improved. In November 1711 Jefferyes had again urged his acceptance of the queen's mediation, but had been told that the king, in view of the recent proceedings of the allies, ' had reason to look upon her offers as words of course and compliment rather than anything in reality.' Jefferyes's argument, that those proceedings were the consequence of Charles's own line of conduct, and the result of necessity rather than of inclination, was of no use. Nor had he the least success in urging afresh the removal of the Baltic blockade. ${ }^{70}$ Charles's anger reached its height when Sutton and Colyer at Constantinople in the spring of 1712 , as has been said, succeeded in thwarting his plans of war. Sir Robert himself believed his efforts for peace to have the queen's approval; he was convinced that Charles and those with him were entirely in the French interest, and that their return to Poland would be disastrous to the common cause, ${ }^{71}$ views which were shared and confirmed by Jefferyes. But in August we find Gyllenborg, whose complaints of the ambassador's conduct had been loud, claiming to be officially informed that her majesty's government condemned his proceedings, ${ }^{72}$

D'Alais exposes the position of Hanover: 'On pourroit concourir a l'execution de ce project, si cela se pouvoit faire sans frais et sans exposer ses propres frontieres, dont on cherche seulement $d$ assurer la preservation, comme on l'a souvent declaré, et il n'y a pas apparence qu'on entreprenne rien au delà' (21 Feb. 1713, Record Office, Regencies, 7).

7010 Nov. o.s. 1711, received 23 Jan. o.s. 1712, ibid. Poland.

319 April o.s. 1712, and the rest of Sutton's despatches from December 1711, ibid. Turkey.

;2 22 August, 5 Sept. 1712, ibid. Sweden. St. John had written in April : ' I can't help being of opinion from severall accounts which I see my Lord Dartmouth receives from Sr. Robert Sutton, that both he and Monsr. Collyar have been too busy in acting the part of Mediators at the Port. Since if that matter were intirely ended, we should have much more reason to apprehend the Tsar, tho' we have enough to be jealous of him at present. And, till we have finished our great work with France, it is without doubt our interest to keep the fire alive in those Parts.' And again: ' Sir Robert 
and when Jefferyes was instructed to inform Charles that the queen bad no intention of withdrawing from her guarantees and treaties, that she would have sent a squadron to the Baltic but for the lateness of the season, and would certainly do so in the following year, and that she had the welfare of Sweden seriously at heart, Charles replied that he was now confirmed in his confidence in her good intentions, and that it would be his constant resolution to maintain with her a sincere friendship. ${ }^{73}$

The belief that Charles was intriguing with France to the detriment of the allies was natural, but had no foundation in fact. In the first place he denied it himself, and assertions by him are to be credited. In the second place in a despatch to his envoy at Constantinople, while instructing him to cultivate good relations with the French ambassador, and to intimate that he was displeased with the sea powers, and might be led to take measures against them, he stated on the other hand that, as a member of the German empire, he would not help France against the emperor. ${ }^{74}$ And thirdly we have the statement of the French king. Louis XIV was accustomed to provide the envoys whom he sent abroad with instructions of the fullest and most confidential character. In a document of this kind he complains that throughout the war Charles had declined to respond to his advances, and to give him the aid he had reason to expect. Although he had shown his goodwill by offering to bring him back from Turkey by sea, by sending money and corn to Stenbock in Pomerania, and by letting his ambassador at Constantinople stir up war between Turkey and Russia, yet he had never been able to procure any undertaking in response. ${ }^{75}$

Such was the position of affairs when the treaty of Utrecht brought to a formal end the long struggle between France and the sea powers. According to their protestations the British government should now have actively taken up the cause of Sweden. But it did not do so. The squadron promised to relieve Stenbock in Tönning did not sail. ${ }^{76}$ The reason was that Great Britain, in

Sutton has undoubtedly acted in many things without order, in some against order ; and in the whole he has erred in laying aside the merchant, and affecting to act the Politician.' It was not without reason that the king of Sweden was provoked. (To Whitworth 8 April and 8 July 0.s. 1712, Record Office, entry books, Russia.)

7: Extract from a letter of Charles, 5 Nov. 0.s. 1712, ibid. Sweden, misplaced as though of 1713. Cp. Jefferyes, 10 Nov. 0.s., ibid. Poland. The latter advised that the chief service the queen could do to Charles would be to procure peace with Denmark.

"t Egenhaindiga Bref, p. 329, 19 Nov. 0.s. 1711.

is Instructions to the count de Croissi, 1715, Recueil des Instructions donnes aux Ambassadeurs ct Ministres de France: Suede.

ia This was the subject of earnest appeal from the Swedes in February 1713 (Gyllenborg and others, Record Office, Sweden; Vellingk's letters, printed in vol. vi. of the Handlingar rörande Skandinaviens Historia). Bolingbroke (St. John) a month before the treaty was signed instructed Shrewsbury in Paris to assure the 
freeing herself from foreign engagements, deprived herself of allies. The treaty of Utrecht, which secured for her great commercial advantages, alienated her continental friends. It sacrificed that leadership in Europe which William had inaugurated and Marlborough by his victories confirmed. Holland had profited little by the peace; she was hard pressed by the claims of Prussia, and financially was on the verge of bankruptey. ${ }^{77}$ Austria, left to fight France with only such aid as the empire could afford-and indeed her persistent pursuit of private ends during the war deserved no better fate-felt and resented the desertion of the sea powers; the emperor even excluded them from a part in the Brunswick conferences. $^{78}$ The elector of Hanover, now on the worst terms with the tory ministry in England, was as determined an enemy of France as the emperor himself. He declared, as St. John had done, his inability to interfere in the affairs of the north while the French war lasted. ${ }^{79}$ No sufficient aid was to be expected from the minor princes of Germany. It was earnestly sought from the new friend, France, but Louis XIV was in no condition to co-operate except by words.

Consequently the British government found that, if they would interfere in favour of Sweden, they must do it by themselves. But that they dared not. To support Sweden by force was to quarrel with the tsar. If Holland would join in such a strife it might be risked; but Russia now controlled in great measure the Baltic commerce, and if Great Britain opposed her alone the Dutch would regain their former monopoly. No action could be ventured, except conjointly with the states-general or with France, the power, to use the words of Bolingbroke, ' which can best be played off against the Muscovite.' 80

During the remainder then of Anne's reign the help her ministers could give to Sweden was confined to diplomatic negotiation, to Swedish envoy there that 'a very strong squadron' was being got ready (3 March 0.8., Gilbert Parke).

"Droysen, Geschichte der preussischen Politik, Iv. ii. 6 foll.

78 This was resented by the British government. Bromley, wrio in August 1713 succeeded Bolingbroke as secretary of state for the northern province, wrote to the peace plenipotentiary Robinson, bishop of London, instructing him to consult with the Dutch ministers upon what should be done in regard to 'such an unaccountable treatment of the States as well as of her Maj'y, who thô she is not fond of being a Mediator, yet sees no reason why she should be in such a manner excluded from it after the Gaaranties she has given' (November 1713, Record Office, entry books, Holland; cp. to Pulteney at Copenhagen, 11 Dec. 0.s., and Pulteney to Strafford, 25 June 1714, ibid. Denmark).

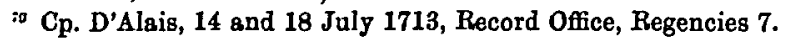

so To Bhrewsbury, 29 May 0.s. 1713, Gilbert Parke. The Dutch, wrote Palteney to Strafford a year later (25 June 1714, Record Office, Denmark), imagined that England would have to do the work, and they share the benefit, not to say obtain important advantages in trade with Russia. The French no doubt had views to the same effect; otherwise they would be foremost to succour Sweden, instead of being loth even to join England in the matter. 
exhortations which were ineffectual, and threats which were disregarded. They took refuge in denying the force of guarantees to treaties, whose provisions they averred had not been observed by the parties themselves. The defensive treaty of 1700 , now the special subject of Gyllenborg's appeals, could not, they said, oblige the queen to engage in an offensive war, or make her 'a partner in all the new designs grafted upon the original quarrel.' The queen would not, indeed, sit by to see Sweden subdued, and the balance of power in the north destroyed, but if she was to interfere the Swedes must definitely declare their willingness to treat for peace. On the other hand the ministers of Denmark, Russia, and Poland were informed of the importunate demands made upon the queen to fulfil the guarantees and the obligations of the defensive treaty, and were admonished that neither she nor the French king nor the states-general would allow the ultimate catastrophe to be accomplished. Let their masters take heed in time, and not refuse to meet $S$ weden in the negotiation into which she was being urged to enter. ${ }^{81}$

At the Hague Strafford made a special effort. At a meeting of the ministers of the powers interested he advised that the good offices of the sea powers should be offered to procure a peace, and that a plan therefor should be submitted to the combatants, the part of those who accepted it to be taken against those who declined it. The ministers were requested to state the pretensions of their various courts as a basis for the plan. This was in July; on 7 August he presented a memorial about Tönning. The town, he protested, having been evacuated by Stenbock, and the Russian and Saxon troops withdrawn, there was no further reason for prosecuting war in those parts. 'The action of the Danes in no way helped them in the war with Sweden, since Tönning was not Swedish. But the careful and evasive reply of the states-general amounted to a refusal, and Stafford's exertions remained fruitless..$^{82}$

And so with France. Bolingbroke as late as July 1713 indulged the hope that the probability of interposition by Louis XIV might move the Dutch to action, ${ }^{83}$ but in August he had to confess its futility. The queen, he wrote to Pulteney, would do nothing, waiting ' for such incidents as either chance or management may create

81 See especially Bolingbroke's despatches to Scott at Dresden, 27 March o.s. 1713, to Shrewsbury, 19 April o.s. (Gilbert Parke), to Pulteney at Copenhagen, 3 May o.s.; then after Stenbock's capitulation in almost identical language to Scott, Pulteney and Wich, 26 May o.s., to Shrewsbury, 29 May 0.8., and to Jackson, 30 May 0.s.; and finally Bromley to Jackson, 15 Sept. o.s. (Record Office, entry books, Poland, Denmark, Hamburg, Sweden).

82 Documents in Lamberty, viii. 307-12. One reason which the Danes alleged for the necessity of crushing Holstein-Gottorp was that the young duke, as son of Charles's elder sister, was heir to the throne of Sweden, and that the possession of his dominions by that crown would be too dangerous for themselves to endurc.

i3 To Shrewsbury, 4 July 0.8., Gilbert Parke. 
in order to dispose the parties concerned to a reasonable composition.' ${ }^{84}$

Charles in the meanwhile was no whit cast down by the events of February, the capture of his person and his removal to Demotika. His prospects, improved for a time, ${ }^{85}$ had gone from bad, when a third peace between Turkey and Russia was probable, to worse, when it was concluded and ratified. ${ }^{86}$ Yet he still demanded the execution of the guarantees. ${ }^{87}$ In a declaration delivered by Gyllenborg in September ${ }^{88}$ he expressed his entire dependence on the friendship of the queen, and on the accomplishment of the promises made to him, professing solely to desire by her good offices a solid and honourable peace, which, however, must not be imposed upon him, but be the result of an enforcement of the treaties. ${ }^{.9}$ 'The queen might, he suggested, announce publicly her intention of not withdrawing from those treaties-a proceeding the more necessary, seeing that the general report to the opposite effect had done him infinite harm at the various courts of Europe. At the Porte in particular so much mischief had been done that, remembering also the ill-conduct of Sir Robert Sutton, he might possibly have lost his faith in the good intentions, the friendship, the justice of the queen. A declaration such as he proposed would restore his confidence.

Moreover Charles continued his negotiations with other powers, in particular a very private and perfectly futile one with Augustus. ${ }^{90}$ Many members of the Swedish senate would have been glad to have a peace forced upon them in spite of their monarch, but act contrary to his injunctions they dared not, fearing for their heads; and they were compelled to declare $80 .{ }^{91}$ Charles entirely declined to have peace imposed upon him against his will, and still refused mediation, whether by the sea powers or by the emperor. ${ }^{92} \mathrm{He}$

st 12 A.ug. o.s., Record Office, entry books, Denmark.

85 Fabrice to Goertz, 17 and 29 March 0.s. 1713.

so Sutton, 12. May and 15 Sept. 0.s., Hecord Office, Turkey. On the latter date Sir Robert wrote: 'Whatever is now desired by the King of Sweden, his Ministers or Officers, is certainly refused.' Charles was now confined at Demirtash, or Timurtash, a seraglio of the sultan half an hour from Adrianople (Jefferyes, 13 May and 12 June o.s., ibid. Poland; Fabrice, 14 April o.s.). He was taken back to Demotika in December (Sutton, 18 Dec. o.s. loc. cit.)

${ }^{87}$ To Queen Anne, 15 May 0.8. 1713, 'a Demitache auprez d'Adrianople' (Record Office, the original in Sweden, Royal Letters). The answer to this letter, 1 Oct o.s., is printed by Lamberty, viii. 326 .

as 3 Sept. o.s., Record Office, Sweden.

89 Egenhandiga Bref, p. 396.

so See Carlson, p. 51 ff.; Egenhändiga Bref, p. 397. He also turned now to France.

91 Jackson from Stockholm, July, \&c., 1713 ; the bishop of London to Bolingbroke, Utrecht, 8 May 1713, holograph; Gyllenborg, 10 Sept. 0.8. 1713 (Record Office, Sweden).

92 Carlson, pp. 50, 58; cp. Egenhädiga Bref, p. 396.

voL. XVI.-NO. LXIV. 
even sent instructions to enforce in full rigour the Baltic blockade, which the senate had for some time past relaxed. Certainly no assistance to those who sympathised with the country was to be obtained from the king.

Desirous then to save Sweden, but thwarted by Charles, incensed on various grounds with Denmark, but fearful of a breach with Russia, resolved against single intervention, but unable to procure help, the British government viewed with satisfaction a new development in northern affairs, which formed indeed an incident such as Bolingbroke had hoped for. This was the intervention of Prussia, which happened not so much in consequence of her inclusion in the peace of Utrecht as because the accession of a new king made her mistress of her own resources.

Frederick, the first king of Prussia, always paid earnest heed to the doings of his Swedish and Polish neighbours. More than once he was on the point of joining either Charles or Augustus, to have his share of any spoils that might result. The old Hansa town of Elbing was his special object of desire; after that Stettin and as much of Swedish Pomerania as might be attached thereto. But there were yet greater attractions in the west, Juliers and Berg, Neuchâtel and Vallengin, the Orange inheritance, prizes which could only be obtained by adherence to the grand alliance. Now Frederick was drawn in one direction, now in another, lowering more and more by his vacillation the credit of his state. ${ }^{93}$ The ultimate cause that limited his action to the west, and kept his splendid troops employed year after year in Italy or in the Netherlands, was an empty treasury. An incompetent, not to say corrupt administration, unsound finance, and extravagant expenditure on vain display made the successor to the great elector as dependent as any other German prince upon the gold of the sea powers.

The first act of Frederick William, his son, was to dismiss hordes of court functionaries, to reduce with ruthless hand salaries and pensions, to save money by every possible economy. The able, if untruthful, Ilgen headed a triumvirate for the conduct of public policy; every department of state was subjected to searching

9s 'Während der grosse Doppelkrieg im Norden und um die spanische Succession dem preussischen Stant immer neue Gelegenheit bot, seine Bedeutung in Deutschland und in Europa zu entwickeln, liess Friedrich I unter dem rastlosen Doppelspiel höfischer und fremder Einflüsse sich mehr und mehr zur Seite schieben, sich schon auch von Kursachsen, von Hannover überholen, sich schon auch in seinem Recht auf die oranische Erbschaft verkürzen. Die anderen Mächte, die grossen wie kleinen, gewöhnten sich daran, dass man Preussen nicht zu fürchten und nicht zu schonen brauche, dass man es missachten und missbrauchen dürfe' (Droysen, Geschichte der preussischen Politik, iv. ii. 4). Under Frederick I, writes Waliszewski, ' la Prusse a suivi un système que l'on pourrait résumer ainsi : ne rien faire, mais tâcher d'obtenir quand même quelque chose; laisser les sutres se battre et profiter de la bagarre pour s'adjuger une part du butin' (Pierre le Grand, p. 370). 
reform; the money saved was devoted to the army. ${ }^{94}$ Prussia began to be the great military state which she has remained since. Master of his own troops, Frederick William could look the confederates in the face and bring them to an understanding.

Had Charles been of another temper, Frederick William might perhaps have been his ally, instead of, as he became, an annexer of his provinces under guise of neutrality. His father, in the previous year, unable to obtain from Peter the Great the objects he desired, had imagined a confederacy in opposition. The main condition was that Charles should allow Stanislaus to resign, as he desired to do, the Polish crown. That done, Augustus recognised, an army of 60,000 Prussians, Swedes, Poles, and Saxons would recover for Charles his lost provinces, and drive Peter back behind his old frontiers. Prussia was to have Elbing, and anything else that might offer without prejudice to her allies. That Charles himself should return home was indispensable..$^{95}$

But Charles had declined. That his proposed allies could hardly have been depended upon to carry out the scheme was not the ground of his refusal. Partly his sense of honour again objected; he had made Stanislaus king, and Stanislaus must remain so; partly he chose still to rely upon the sultan, who in November 1712 declared war upon Russia for the third time. The news of Stenbock's landing in Pomerania steeled his resolution. That Prussia should fight for him was well enough; but to restore his rights, not for her own profit. The chance was lost: Frederick died, and Frederick William was free to pursue his own course with regard to Sweden. The friendly letter, desiring his alliance and support, which Charles wrote to him from Demirtash in May, ${ }^{96}$ could not reach him until the policy now to be described was complete.

He entered the arena as a friend of Holstein-Gottorp. A treaty of June 1713, arranged by the Holstein minister Goertz, and approved by Vellingk, provided that Stettin and Wismar should be occupied jointly by Prussian and Holstein troops until the conclusion of the war. On the other hand the king of Prussia was to concert with Great Britain, Holland, and Hanover, or, in the case of refusal of the others, with Great Britain alone, measures to save the dominions of the duke from the clutch of Denmark.

But the treaty was doomed to failure. The commandants of Wismar and Stettin refused to give them up; the latter fortress capitulated only after a long siege, and then fell into Russian hands. The troops of Prussia and Holstein occupied it not by permission

24 See Droysen, rv. ii. 7 ff.

os See Carlson, p. 32 fi. ; Droysen, I7. i. 419 ff.

90 18 May o.s. 1713, Egenhändiga Bref, p. 223. The letter is very instructive as to Charles's views. All the right was on his side, and his enemies were persecuting him 'gegen Treu und Glauben.' 
of the Swedes, but by virtue of a treaty made with Menshikov at Schwedt, a treaty which robbed the Dane and Saxon of their promised booty, and gave the southern shore of the Baltic to be the heritage of Prussia.97

The British government was willing enough that Prussia should pull the Holstein chestnuts out of the Danish fire. ${ }^{93}$ Inquiries at Berlin received the answer that Frederick William was very desirous to concert with the queen all proper measures to compose the troubles. of the north, and awaited communication of her designs. ${ }^{99}$ The king wrote himself to her three times, ${ }^{100}$ earnestly protesting that he fully shared her sentiments in regard to HolsteinGottorp, and inquiring what measures she proposed to take, in order that he might further them. He fully intended, he said, strenuously to exert himself, enixa ririum nostrarum contentione, in the duke's cause; but the king of Denmark would be much more easily controlled if the queen would join her arguments to his own. Bonet in London, Ilgen at Berlin emphasised these expressions, asked for help in men, ships, and money, and added the hope that the British government would favour their master's aspiration, in the end to have Stettin and the neighbouring country for himself. ${ }^{101}$ Their requests were backed by Strafford. ${ }^{102}$ But all in vain. Active aid was refused. Breton was particularly instructed ' not to engage her majesty in any part of the expense necessary for those expeditions.' 103 As to Stettin, he was to 'give room to hope,' but cautiously, and without engaging the queen to anything particular, lest her majesty should be hereafter brought under difficulties to

07 'So der Sehwedter Vertrag, einer der wichtigsten, die Preussen geschlossen hat. Wichtig nicht blos darum, weil er der Grundstein der Entwickelungen, die fortan die nordischen Dinge genommen, geworden ist; es war nach langen Zurückweichen der preussischen Politik ein erster Schritt vorwärts, man darf sagen der entscheidende Schritt' (Droysen, Iv. ii. 59).

os ' We are of opinion that the Treaty made by the Administrator of Holstein with the King of Prussia might prove some skreen to Sweden, might give then some breathing time, and afford to their friends a foundation whereon to raise somewhat of advantage to them' (Bolingbroke to Jackson, 18 Aug. o.s. 1713, Reeord Ofice, entry books, Sweden). 'As to the Dutchy of Holstein, it is agreed on all sides that the only method now left to preserve it will be that of a Sequestration into the hands of the King of Prussia, which the Queen will press his Majsy to take upon him' (Bromley to the same, 15 Sept. o.s. ibid.) As neither the states-general nor the elector of Hanover would send troops to succour Tönning, ' nothing remains to sare that place and country, but the King of Prussia's taking upon bin the sequestration of Holstein ' (Bromley to Breton, same date, ibid. Prussia).

99 Breton from Berlin, 10 June 1713, ibid.

10015 Aug. 1713, ibid. (copy or translation); 4 Nor. 1713 and 23 Jan. 1714, ibid. (royal letters, the Latin originals).

10 Bonet, Nov. and Dec. 1713 ; Breton, 5 Aug., 31 Oct., 11 Nov. 1713, 17 Jan., 14 April 1714, ibid.

102 1, 15, and 29 May 1714, ibid. Holland. See also Bromley's despatches to him in this month.

${ }^{103}$ Bromley to Breton, 26 Oct. 0.s. 1713, ibid. entry books, Prussia. 
perform it, from his Swedish majesty's intractable temper.' 104 What could be done by words was done. The king of Denmark was urged to agree to the inclusion of all the dominions of HolsteinGottorp in the sequestration. ${ }^{105}$ When Rosenkrantz, the Danish minister in London, complained that the king of Prussia was endeavouring by his letters to excite the queen to hostile action against Denmark, answer was made to him that whoever first broke the neutrality of Holstein, the Swedes having evacuated the country, that neutrality should be restored. ${ }^{106}$ When in February 1714 Tönning fell, and the battle near Wasa sealed the fate of Finland; when a Danish army was expected to cross the Sound, a Russian fleet to capture Stockholm ; the Swedes were urged to make Frederick William their friend by ceding to him Stettin, rather than let him owe its acquisition to their enemies. ${ }^{107}$ But the help asked for was not granted, and the scheme of Prussian intervention in favour of Holstein-Gottorp from this and other causes fell through.

In the meantime Sweden was on the verge of revolution. Taxes had long been intolerable and impossible. The loss of Finland, the granary of Stockholm, was ascribed to treachery. A report spread of Charles's death. The senate was compelled to put the princess Ulrica at its head, and to summon the estates. Vellingk was authorised to conduct negotiations for peace in its name. But then, towards the end of January 1714, came letters from Charles absolutely refusing peace, and expressly ordering the dissolution of the estates, if they had been convoked. Consternation reigned, ruin seemed imminent. An outbreak was only averted by the firmness of Chancellor Horn. The senate declared that they must obey the king; that it only remained to fight desperately to the end, and so perish. ${ }^{108}$

104 The same, 13 and 17 Nov. o.s. ibid. To Bonet Bromley wrote, 25 Nov. o.s. : ' La Reine ne se croyant pas en droit de disposer des Places d'autrui, Elle ne sauroit pas s'engager que Stetin ni aucune autre Place nommement lui soit cedée par cette Couronne.'

105 Bromley to Pulteney, 14 Oct. o.s. 1713, ibid. Denmark.

jos Ibid. 13 Nov. 0.8 .

107 Bromley to Strafford, 26 March and 27 April o.s. 1714, ibid. Holland; cp. Bolingbroke to the same on the latter date (Gilbert Parke).

103 Jackson; October 1713 to January 1714; appeal of the princess and senate of Sweden, 27 March o.s. 1714, delivered by Gyllenborg 2 May 0.s.; ibid. Sweden. See Bain's account of the state of the country and of the proceedings of this riksdag in his Charles $X I I$, p. 254 ff.

Here may be noted a striking memorandum of Vellingk to Sparre at Paris, of date 23 April 1714, printed in the Handlingar rörande Skandinaviens Historia, vi. 226. The writer urged that it was of the last necessity that Charles should consent to the negotiation of a general peace. A reconciliation with Augustus was indispensable, seeing that the king of Prussia would engage himself to nothing without this. Charles ought not to persist in being the only one to refuse the emperor the title of king of Spain. He should rather send a minister of importance to Vienna. The old friend- 
In the meantime the renewed rigour of the Baltic blockade, causing increased clamours on the part of the mercantile community, and a growing scarcity of naval stores, forced the hands of the British government. It was determined to send to the Baltic a small squadron of men-of-war to convoy the traders. But the uncongenial resolve was accompanied by fresh efforts to procure peace. Strafford at the Hague, Matthew Prior at Paris were instructed to make every possible endeavour to obtain concerted action. ${ }^{109}$ At Copenhagen more threats were launched. The queen, it was declared, would resume reluctantly the arms laid down, rather than suffer Sweden to be totally destroyed. Although the parties in the war were all her friends, although Frederick was her near relation, she must interpose. The growing power of the tsar in the Baltic was as dangerous to Denmark as to others. ${ }^{110}$ To Russia was despatched George Mackenzie, formerly at Dresden. His instructions ${ }^{111}$ included a strongly worded paragraph in favour of Sweden, described as a nation with whom the queen had important alliances, and in whose preservation the interest of her people was deeply concerned. The tsar was to be induced to assent to a peace, reaping thereby glory and the fruits of his successes.

But these representations had no better result than former ones. The states-general only replied to the queen's letter of 25 March that they would be glad to help in procuring a good peace, but were overcome by embarrassments resulting from the late war. Deputies told Strafford that they had little inclination to aid Sweden, who had done their commerce so much barm. $\mathrm{He}$ notified that the Dutch would do nothing that might be disagreeable to any of the confegderate princes or to the emperor, that their chief interest was in the completion of their Barrier treaty, and that if they took action in regard to the Baltic trade it would be on their own account, and not conjointly with the queen. Neither the Dutch nor the French could be prevailed upon to join either in active measures or in a congress to procure peace. ${ }^{112}$

Foreign nations in fact declined to place any dependence upon a ministry accused of betraying its allies and known to be shattered by internal dissension. Its declarations and threats were laughed at on the continent. Goertz could write from Berlin-

Je vous dis à regret que tout ce que l'on sauroit prêcher à la Cour

ehip too with Hanover should be restored, especially in view of the high credit the elector now enjoyed and the respect held for him by the tsar.

${ }^{109}$ Bolingbroke to Prior, 6 May o.s. 1714, Record Office, entry books, France. He sets forth the situation at length.

"1o Bromley to Pulteney, 4 May o.s., ibid. Denmark.

11123 May 0.8. 1714, ibid. Russis.

112 Strafford, March to August 1714, ibid. Holland. 
ioy de la vigueur de la Cour Britannique n'est regardé que comme des chansons. ${ }^{113}$

\section{A Danish statesman}

se mocquoit des menaces de l'Angleterre, étant convaincu qu'Elle n'oseroit rien faire par la crainte qu'Elle a pour le Czar, qui ne manqueroit pas de faire massacrer les Marchands Anglois, et de se saisir de leurs effets. ${ }^{114}$

Prince Kurakin told Strafford that his master had ships of war as well as the English and Dutch, and did not see what right they had to send fleets into the Baltic. ${ }^{115}$

The squadron prepared consisted only of three ships, the 'Woolwich,' 'Dolphin,' and 'Flamborough.' The command was entrusted to Captain Archibald Hamilton. By his first instructions from the admiralty, of date 9 July old style, he was to accompany the merchantmen all the way to St. Petersburg. Later he was ordered to take particular care to protect them from any Swedish men-ofwar with which he might fall in. But on 1 August he sent in news of thirty Dutch and English sail seized and taken into Stockholm, and further on the 4th that twenty-four Swedish men-of-war, of from 30 to 70 guns, were on the look-out, with orders to 'sink by their sides' rather than allow English or any other ships to reach the forbidden ports. Fresh instructions, therefore, were given to him on the 7th to the effect that on his arrival at Elsinore he was to inform himself by every possible means whether the news be had reported were true, and if he found it to be so to return with as many of the merchantmen as would accompany him to the Nore. ${ }^{116}$

He did ascertain the truth of the report, and he did not enter the Baltic, but the story of that belongs to the next reign. Six days before the last-named instructions were given him Queen Anne died, and the sovereignty of her kingdoms passed to her foreign cousin.

J. F. Chance.

11326 June 1714, ibid. Sweden. See also there to the same effect extracts from letters of Sparre, Vellingk, and others to Gyllenborg in May and June.

ii. Pulteney to Strafford, 25 June, ibid. Denmark.

i1s Strafford, 6 March, ibid. Holland.

$" 16$ Record Office, Admiralty, Orders and Instructions 46, Captains' Letters, H 9. According to Bromley (ibid. Secretary of State's Letters 13, 15 July o.s.; and Home Office, Regeneies 11, 7 August o.s.) four ships were appointed. But only the three mentioned sailed. 